\title{
Influence of benthic fauna on trimethylamine concentrations in coastal marine sediments
}

\author{
Jan Sørensen, Elsebeth Glob \\ Department of Ecology and Genetics, University of Aarhus, Ny Munkegade, DK-8000 Aarhus C, Denmark
}

\begin{abstract}
Seasonal variation of trimethylamine (TMA) concentrations in sediment porewater was detected at 3 different sites in a Danish estuary. A significant increase, from a pool size of 0 to $0.5 \mu \mathrm{M}$ in fall and winter to 5 to $10 \mu \mathrm{M}$ during spring, was observed in 2 fauna-rich, sandy sediments. An organicrich silt with few animals showed low TMA concentrations throughout the season. Depth profiles of TMA also correlated with the distribution of burrowing infauna. Only fauna-rich sediments showed detectable efflux of TMA to the water phase. With few animals, the flux was negligible due to efficient TMA consumption at the oxic sediment-water interface. Animals are proposed to influence production and emission of TMA by osmoregulation and physical activity in the sediment
\end{abstract}

\section{INTRODUCTION}

Trimethylamine (TMA) appears to be a common constituent of marine sediment porewaters (King et al. 1983, Lee \& Olson 1984). The origin may be the large number of osmoregulatory compounds, mainly trimethylamine oxide (TMAO) and quaternary amines (choline, glycine betaine and others), which are found in marine animals and plants (Strøm 1969, Cavalieri \& Huang 1981, Blunden et al. 1982, Yancey et al. 1982). Several pathways for anaerobic conversion of such TMA precursors into TMA have been described in bacteria (Strøm and Larsen 1979, Fiebig \& Gottschalk 1983, Naumann et al. 1983, King 1984b). However, since marine invertebrates often contain large amounts of TMA in their tissues (Hebard et al. 1982), a direct release from live animals could also be a source of TMA in sediment porewaters.

Recent attention to the metabolism of TMA has been due to its apparent role as a substrate in terminal processes of anaerobic organic matter degradation, i.e. bacterial sulfate respiration and methanogenesis (Oremland \& Polcin 1982, King et al. 1983, King 1984a). TMA turnover may also contribute significantly to nitrogen cycling in coastal sediments (King 1984b). An estimate of TMA degradation in the sediments is best approached by a tracer technique combined with a determination of the natural TMA pool. Previous studies of TMA pools in marine sediments have noted a concentration range of 0 to $30 \mu \mathrm{M}$ in porewaters (King et al. 1983, Lee \& Olson 1984), but none of them have included the seasonal and spatial variations which may be expected in a coastal environment. The purpose of this work was to describe the distribution patterns of TMA in 3 coastal sediments which differed in organic content and abundance of infauna.

\section{MATERIALS AND METHODS}

Sampling sites. The studies were made at 3 sites in the outer, saline part of a Danish estuary (Norsminde Fjord). Average water depth was $0.6 \mathrm{~m}$ and salinity varied from $0.5 \%$ in winter to about $30 \%$ in late summer. Temperature varied from 0 to $20^{\circ} \mathrm{C}$ over the year.

Stns A and B were located on exposed shores where the sediment was sandy silt with an infauna of crustaceans (amphipod Corophium volutator), gastropods (Cardium edule, Hydrobia ulvae, Littorina littorea, Mya arenarea, Mytilus edulis) and polychaetes (Nereis sp.). Stn $C$ was a sheltered site with silt and relatively few animals, mostly Corophium volutator, Hydrobia ventrosa and Hydrobia neglecta. All sediments had a dense surface layer of benthic diatoms in spring. Stn $\mathrm{C}$ accumulated a layer of floating sea lettuce Ulva lactuca in late summer. Other characteristics of the estuarine sediments were given in Sørensen et al. (1979), Jørgen- 
sen \& Okholm-Hansen (1985) and Jørgensen \& Sørensen (1985). In the latter 2 reports, the numbers 1, 3 and 2 were used for Stns A, B and C, respectively.

TMA concentrations in estuarine water and sediment. From April to September 1985, water samples were collected at monthly intervals to follow TMA concentrations in the surface water. Samples were kept stoppered in $120 \mathrm{ml}$ serum bottles until analysis (max. $4 \mathrm{wk})$.

At monthly intervals, from April 1985 to June 1986, 6 undisturbed sediment cores $(15 \mathrm{~cm}$ long and $3 \mathrm{~cm}$ wide) were collected at each station for determination of TMA in porewater. About $2 \mathrm{~h}$ after collection, the upper $10 \mathrm{~cm}$ was fractionated into 0.5 to $2 \mathrm{~cm}$ segments $0.5 \mathrm{~cm}$ for 0 to $4 \mathrm{~cm}$ depth, $1 \mathrm{~cm}$ for 4 to $6 \mathrm{~cm}$ depth and $2 \mathrm{~cm}$ for 6 to $10 \mathrm{~cm}$ depth). Because of the variability among cores, segments from the same depth were pooled and the porewater was extracted by centrifugation (Stns A and B; $1000 \times g, 10 \mathrm{~min}$ ) or pressure filtration (Stn C; $0.2 \mu \mathrm{m}$ polycarbonate filters, $3 \mathrm{~atm} \mathrm{~N}_{2}$ ). The samples were stored frozen $\left(-20^{\circ} \mathrm{C}\right)$ for later analysis (max. $4 \mathrm{wk}$ ).

On one occasion, in August 1985, the KCl-extractable TMA pool (dissolved + exchangeable TMA) was determined in sediment from Stn $B$ according to the $\mathrm{NH}_{4}^{+}$extraction procedure described by Sørensen (1978). About $10 \mathrm{~g}$ wet weight of sediment was extracted in $10 \mathrm{ml} 1 \mathrm{M} \mathrm{KCl}$ solution at room temperature $\left(22^{\circ} \mathrm{C}\right)$. Extraction times were from $2 \mathrm{~min}$ to $1 \mathrm{~h}$, as desired. After centrifugation $(1000 \times g, 10 \mathrm{~min})$, the supernatants were frozen for later analysis (max. $4 \mathrm{wk}$ ).

TMA release from sediment cores. The efflux of TMA to the water phase was determined in 8 replicate cores taken at Stn B in spring 1985. Both dark and light conditions were used; incubations in the light at $200 \mu \mathrm{E}$ $\mathrm{m}^{-2}$ was sufficient to saturate photosynthesis in the micro-algal layer (Revsbech et al. 1983). Clear Plexiglas caps on top of the cores prevented both a loss of TMA and served to hold a small magnetic bar for stirring of the water phase (Jensen et al. 1984). In situ temperature $\left(16^{\circ} \mathrm{C}\right)$ was maintained throughout $7 \mathrm{~h}$ of incubation.

Faunal influence on TMA emission was studied in 6 replicate, artificial sediment cores. Surface sediment from Stn B was first sieved ( $250 \mu \mathrm{m}$ mesh) to remove the larger infauna, and then distributed into $3 \mathrm{~cm}$ wide Plexiglas tubes to settle for $40 \mathrm{~h}$ at in situ temperature $\left(16^{\circ} \mathrm{C}\right)$. The water phases were thereafter replaced with $40 \mathrm{ml}$ of surface water from the estuary and stirred continuously as described for natural cores. A number of freshly collected Corophium volutator specimens $(0.3 \mathrm{~g}$ fresh weight or about 60 adult specimens per core) was added to 2 of the cores. TMA concentrations were measured in the water phase of the cores during $3 \mathrm{~h}$ of dark incubation.
TMA excretion by iauna. To determine if TMA was excreted by the infauna, we incubated a number of Corophium volutator specimens $(0.2 \mathrm{~g}$ fresh weight or about 40 adult specimens) in oxic surface water from Stn B (30 ml, $12 \%$ salinity). Similar incubations were made in river water from the upper part of the estuary $(0.5 \%$ salinity) and in $\mathrm{NaCl}$-enriched water collected at Stn B (34\% salinity). All incubations were made at in situ temperature $\left(16^{\circ} \mathrm{C}\right)$ in the dark and TMA concentrations were followed for a period of $8 \mathrm{~h}$.

TMA content in fauna. To determine the TMA content in the most abundant representative of the infauna, we homogenized about 30 freshly collected Corophium volutator specimens (about $0.15 \mathrm{~g}$ fresh weight) in $10 \mathrm{ml}$ trichloracetic acid solution (TCA, $7.5 \%)$. After centrifugation $(1000 \times \mathrm{g}, 10 \mathrm{~min})$, the TMA concentration was determined in the extract.

TMA analysis. Similar procedures, including type of glassware, pipettes, etc., were used for standard solutions and natural samples. Freezing $\left(-18^{\circ} \mathrm{C}\right)$ and longterm storage $(3 \mathrm{mo})$ did not affect the TMA concentrations in standard solutions $(0$ to $10 \mu \mathrm{M}$ TMA in $15 \%$ seawater from the estuary).

TMA was analysed by gas chromatography as described by Glob \& Sørensen (in press). In brief, a volatilization of TMA was obtained by addition of base to the sample. The gaseous TMA was first transferred to a cryogenic trap (liquid $\mathrm{N}_{2}$ ) by a sparge with He gas (25 $\left.\mathrm{ml} \mathrm{min}^{-1}\right)$, and then injected into a gas chromatograph. One $\mathrm{ml}$ of sample, $0.1 \mathrm{ml} 20 \mathrm{mM} \mathrm{NH}_{4} \mathrm{Cl}$ and $0.2 \mathrm{ml} 10 \mathrm{M} \mathrm{NaOH}$ were injected simultaneously into the sparging chamber. The sample components were separated on a $2 \mathrm{~m}$ long and $6 \mathrm{~mm}$ wide glass column containing 60/80-mesh Carbopack B coated with $4 \%$ Carbowax $20 \mathrm{M}$ and $0.8 \% \mathrm{KOH}$ (Di Corcia et al. 1979). All glassware was treated with $5 \%$ DMCS in toluene (silanization) and connections were of FEP Teflon. The spike of $\mathrm{NH}_{3}$ gas was included to reduce TMA absorption to surfaces and to give better elution from the chromatographic column. Carrier gas was He at a flow rate of $20 \mathrm{ml} \mathrm{min}{ }^{-1}$ and oven temperature was $85^{\circ} \mathrm{C}$. An FI detector operated at $250^{\circ} \mathrm{C}$ was used.

Concentrations of TMA were expressed in $\mathrm{nM}$ or $\mu \mathrm{M}$ for the aqueous samples. The $\mathrm{KCl}$ extractable pool was expressed in $\mathrm{nmol} \mathrm{cm}^{-3}$ of sediment, after corrections for density and water content. Faunal TMA contents were expressed in $\mu \mathrm{mol} \mathrm{g}^{-1}$ fresh weight of animal.

\section{RESULTS}

\section{TMA concentrations in the estuary}

TMA concentrations were generally very low in the surface waters of the estuary; a range of 2 to $20 \mathrm{nM}$ 
TMA was representative for the outer estuary in spring and summer (data not shown). Exceptionally high concentrations, 1 to $2 \mu \mathrm{M}$, were observed only where degrading macro-algae (Ulva lactuca) accumulated in the stagnant water of sheltered parts of the estuary.

High levels of TMA were found in the upper few $\mathrm{cm}$ of the sediments (Fig. 1). Highest concentrations were observed at the sandy stations A and B which also had TMA to the greatest depth throughout the season. The 2 stations further demonstrated a marked seasonal variation in the TMA distribution: high concentrations to considerable depth were found in spring and early summer. Stn A sediment thus had a maximum of 5 to
10 uM TMA at about 0 to $2 \mathrm{~cm}$ depth and elevated concentrations extending to at least $10 \mathrm{~cm}$ depth. The low concentrations of 0 to $1 \mu \mathrm{M}$ TMA observed in fall and winter were located within a smaller depth interval from 0 to $4 \mathrm{~cm}$ depth. In winter, a subsurface maximum could be distinguished at 2 to $4 \mathrm{~cm}$ depth. A similar concentration range was found at $\operatorname{Stn} B$, with a maximum of 2 to $5 \mu \mathrm{M}$ in spring and a minimum of 0 to $0.5 \mu \mathrm{M}$ in fall and winter. The profile extended to about $6 \mathrm{~cm}$ depth in the spring and contained, as for Stn A, a subsurface maximum at 2 to $4 \mathrm{~cm}$ depth in fall and winter. Stn $C$ had much lower TMA concentrations in the sediment and a maximum of about $1 \mu \mathrm{M}$, recorded
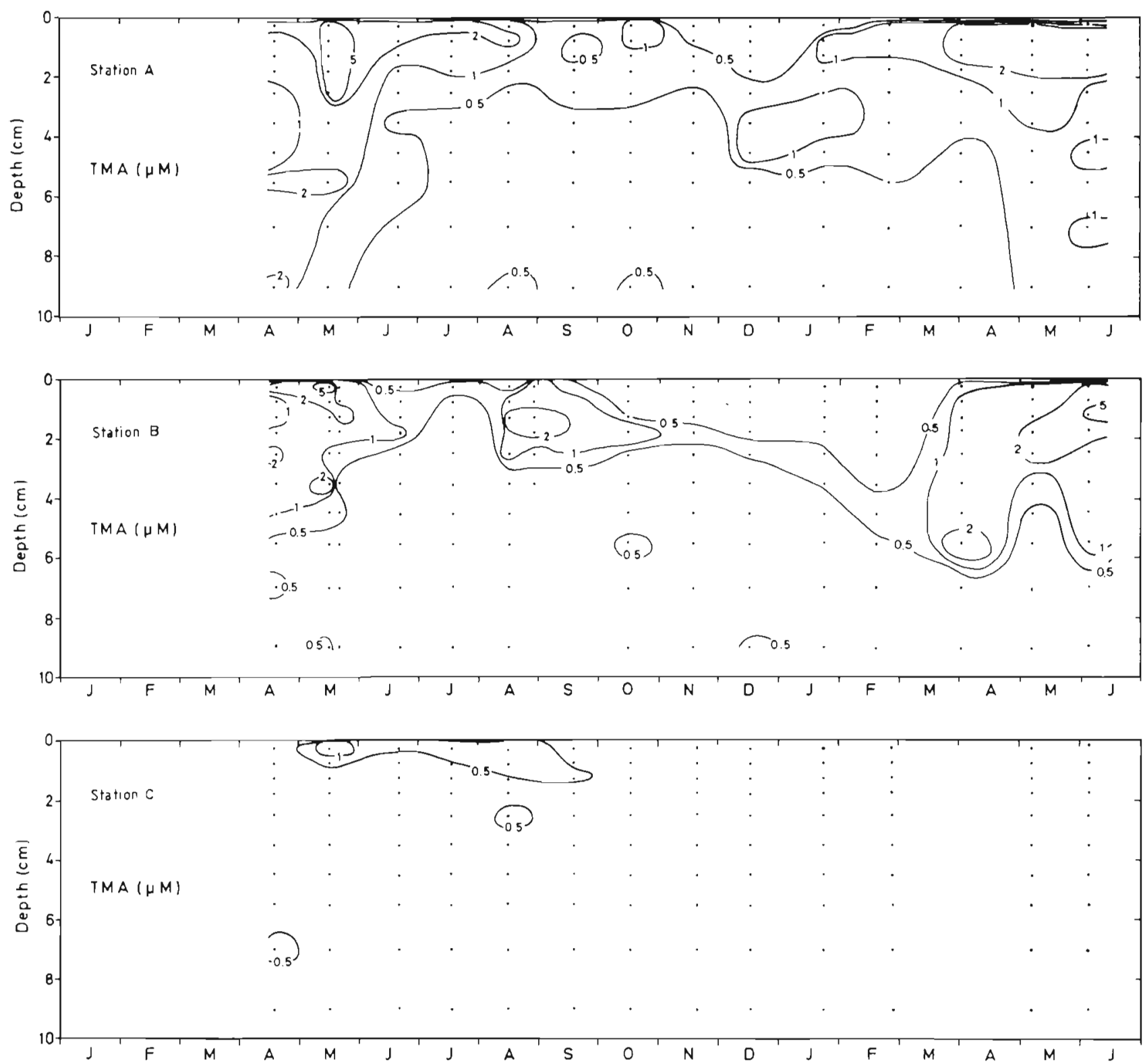

Fig. 1. Seasonal variation of TMA concentrations in porewater from 3 estuarine sediments (Stns A, B and C, Norsminde Fjord, 1985-86) 
at 0 to $1 \mathrm{~cm}$ depth in spring, was seen only during the first year of study.

\section{Efflux of TMA from sediment}

The efflux of TMA from the sediment cores resulted in fluctuating TMA concentrations in the water phase. Core 1 in Fig. 2 represents a pattern observed in 6 out of 8 cores collected for such measurements. During the $7 \mathrm{~h}$ incubation, concentrations changed several times between a minimum of 20 to $30 \mathrm{nM}$ and a maximum of about $100 \mathrm{nM}$. Two of the 8 cores maintained a low and constant TMA concentration of 20 to $30 \mathrm{nM}$ in the water phase (Core 2 in Fig. 2). Light exposure had no apparent effect on the efflux of TMA (data not shown).

When 2 artificial cores of sieved sediment were supplemented with Corophium volutator specimens, we observed a short-term fluctuation for TMA in the water phase similar to that occurring in most of the natural cores. Fig. 3 shows the results from one of the artificial cores; during the $2 \mathrm{~h}$ incubation, TMA concentrations varied from a low level of $2 \mathrm{nM}$ to a high level of 20 to $60 \mathrm{nM}$. By comparison, 2 control cores without amphipods showed a low and constant TMA concentration throughout the incubation. The result from one of them is shown in Fig. 3. After incubation, the faunasupplemented cores had about 4 times higher TMA

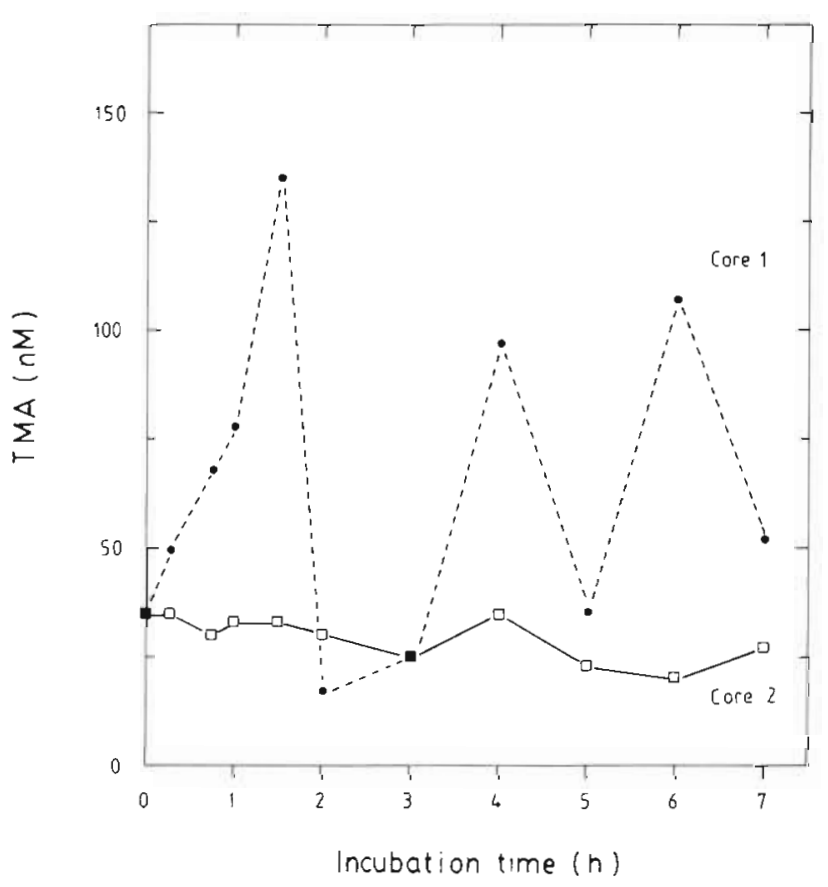

Fig. 2. Time course showing TMA concentrations in the water phase of 2 sediment cores from Stn B. Cores were collected in spring 1985 and incubated at in situ temperature $\left(16^{\circ} \mathrm{C}\right)$, salinity $(16 \%)$ with stirring of the water phase

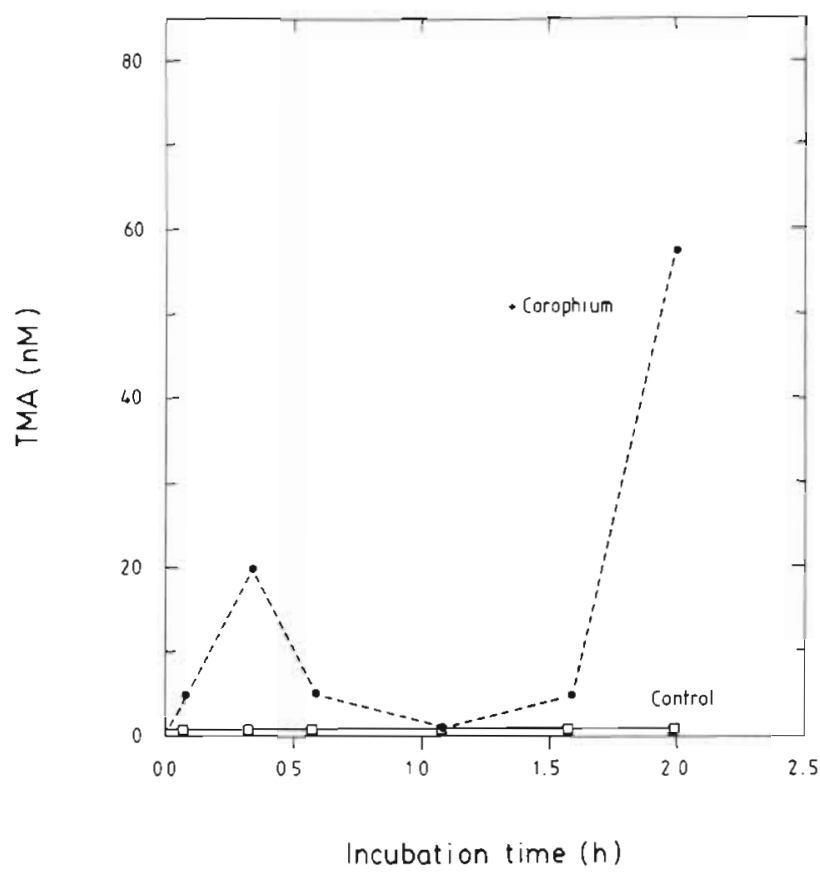

Fig. 3. Time course showing TMA concentrations in the water phase of 2 cores of artificial sediment (0 to $250 \mu \mathrm{m}$ fraction of the oxidized surface layer from Stn B). Sediment was, collected in spring 1985 and cores incubated at in situ temperature $\left(16^{\circ} \mathrm{C}\right)$, salinity $(21 \%)$ with stirring of the water phase. One of the cores was supplemented with Corophium volutator at its natural density

levels in the porewater than the control cores (data not shown).

\section{Faunal source of TMA}

Fig. 4 shows the dramatic TMA release which took place from Corophium volutator specimens when they were placed in water samples from the estuary. After a short lag, the release was constant for several hours. Incubations in medium-salinity water $(12 \%$; collection at $\operatorname{Stn}$ B) gave a release rate of $20 \mathrm{nmol} \mathrm{TMA} \mathrm{g}{ }^{-1}$ fresh weight $h^{-1}$ A similar lag period, but a 10 - to 200 -fold higher rate, was observed when the amphipods were incubated in high-salinity $(34 \%)$ and low-salinity $(0.5 \%$ ) water, respectively (Fig. 4). The amphipods were always alive during the incubations $(4 \mathrm{~h})$, but lower activity (infrequent respiration) was observed at both the high and low salinity.

Fig. 5 shows the time course for TMA extraction in $\mathrm{KCl}$ for oxidized ( 0 to $1 \mathrm{~cm}$ depth) and reduced (4 to $5 \mathrm{~cm}$ depth) sediment layers. In the latter, the $\mathrm{KCl}$ treatment immediately solubilized an exchangeable TMA pool which was similar in size to the porewater pool (Fig. 5, bottom). Instant release of exchangeable TMA was also observed in the oxidized sediment. However, in this fraction, the TMA release continued 


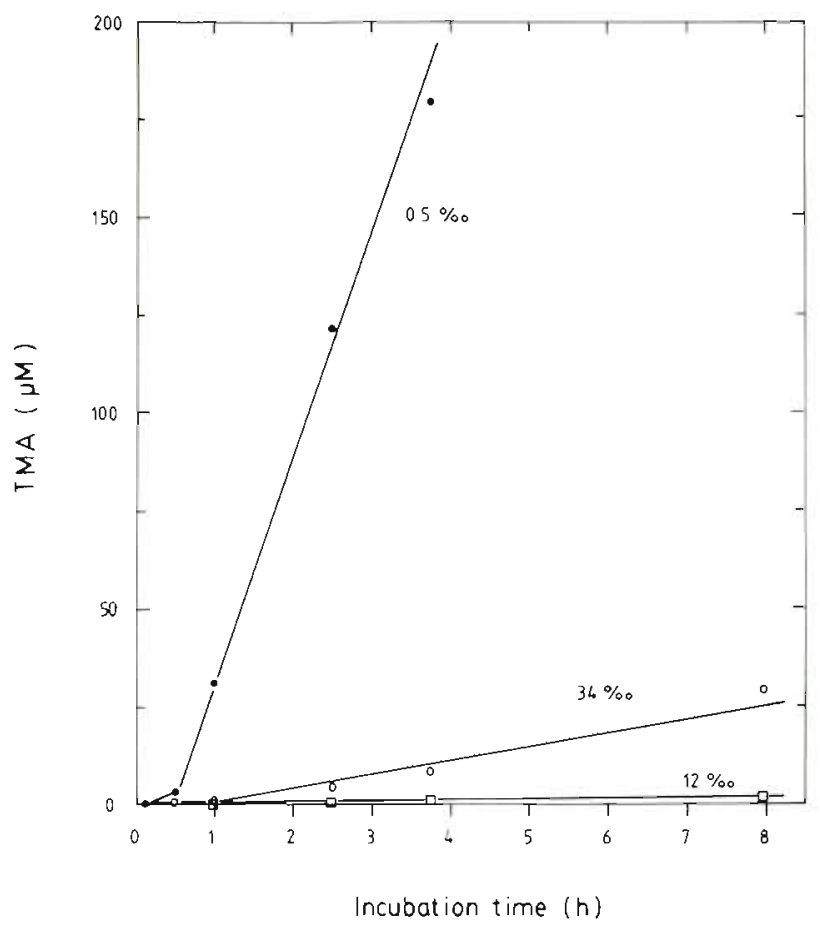

Fig. 4. Time course showing TMA accumulation in water samples supplemented with Corophium volutator $10.2 \mathrm{~g}$ fresh weight in $30 \mathrm{ml}$ of water). Temperature was $16^{\circ} \mathrm{C}$ and salinity as indicated. The amphipods were collected from surface sediment at Stn B (12\% salinity, spring 1985)

for several hours, first slowly (for about $0.5 \mathrm{~h}$ ) and then at a faster rate (Fig. 5, top).

\section{DISCUSSION}

The upper few cm of estuarine sediments are generally characterized by the presence of dense populations of benthic invertebrates several $\mathrm{cm}$ into the sediment. We observed that significant accumulations of TMA were limited to this zone. The correlation between TMA distribution and faunal abundance was supported by the high TMA concentrations (up to $10 \mu \mathrm{M}$ ) which appeared together with a maximum of faunal density in spring and early summer. The TMA concentrations decreased during summer and eventually reached a minimum in winter when animals were relatively scarce. The black and sulfide-containing layers deeper in the sediment are completely anoxic and devoid of infauna. We only found low concentrations of TMA (less than $0.5 \mu \mathrm{M}$ ) in this environment, in good agreement with the values reported by Lee \& Olson (1984) for deeper layers of coastal sediment.

The efflux of TMA from the sediment cores gave further evidence for an influence of the infauna on TMA distributions. Results from artificial cores suggested that net emissions of TMA may be seen only if the sediments contain larger-size fauna. The bursts of TMA emission observed in a number of cores could only be explained by a periodic, physical distortion of the TMA gradient at the surface or a rapid export of TMA-rich porewater when the animals ventilate their burrows. An uneven distribution of infauna among the cores was a likely explanation for the variable emission patterns.

Both the natural and artificial cores demonstrated sequences of net release and net uptake of TMA at the sediment-water interface. The rapid fluctuations gave evidence for an efficient TMA sink at the sedimentwater interface. No efflux was seen when larger-size animals were absent. If taking place by diffusion alone, a TMA flux from deeper layers may thus be matched by consumption at the interface. This control mechanism for minimizing efflux from sediments has been observed for other compounds which are transported upwards by diffusion and consumed rapidly at the oxic interface. One example is the upward diffusion of $\mathrm{NH}_{4}{ }^{+}$
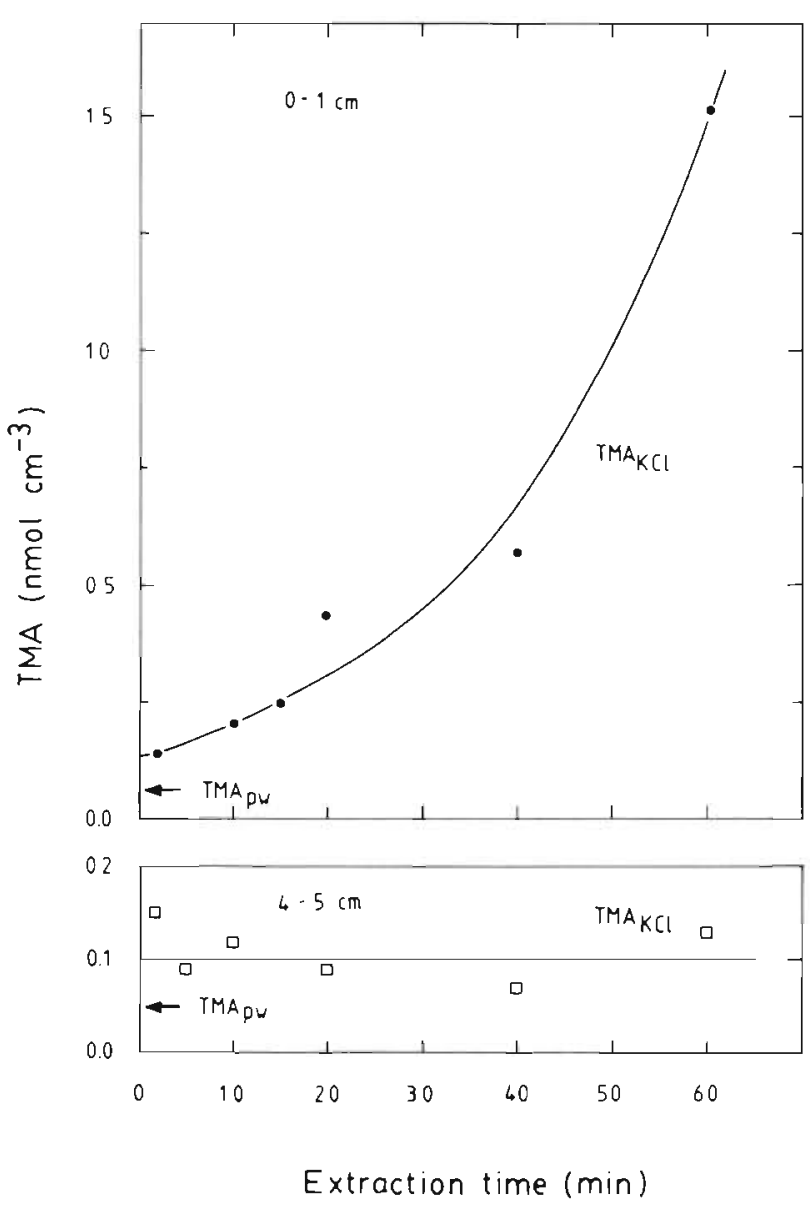

Fig. 5. Time course showing TMA concentrations in $\mathrm{KCl}-$ treated samples of oxidized ( 0 to $1 \mathrm{~cm}$ depth) and reduced (4 to $5 \mathrm{~cm}$ depth) sediment from Stn B (spring 1985). Extractions were made at room temperature $\left(22^{\circ} \mathrm{C}\right)$ with gentle shaking of the samples 
ions which can be matched by bacterial oxidation (nitrification) and uptake by algae in the upper few $\mathrm{mm}$ of the sediments (Henriksen et al. 1984). In such cases, faunal activity may provide an important mechanism for efflux since rapid transport in the burrows bypasses the consumption layer at the interface.

Adult specimens of Corophium volutator contained about $5 \mu \mathrm{mol} \mathrm{TMA} \mathrm{g}^{-1}$ of fresh weight (Glob \& Sørensen unpubl. results). If these amphipods represent a major TMA source in the sediments, a direct release of TMA during osmoregulation is likely to be important. Dramatic excretion took place in C. volutator when the salinity was either increased or lowered, relative to the salinity at their collection site. The lag and subsequent TMA release, which occurred after a change of salinity, were indicative of intensified osmoregulation in the infauna. The very high TMA concentrations obtained in low-salinity water (200 $\mu \mathrm{M}$ TMA after $4 \mathrm{~h}$ ) also suggested that the amphipods released TMA directly from the body fluids.

Other evidence for an important TMA source associated with osmoregulating infauna came from the $\mathrm{KCl}$ treated surface sediment. The pattern of TMA release was here most similar to that described for the water samples with Corophium volutator specimens. Since the oxidized sediment fraction contains a majority of the infauna, the progressive TMA release observed during $\mathrm{KCl}$-treatment was likely to be a faunal response to the altered $\mathrm{Na}^{+} / \mathrm{K}^{+}$composition of the environment (Yancey 1982).

In summary, we report the first evidence for major seasonal variations of TMA concentrations in coastal sediments. We also report that both the distribution patterns and the efflux of TMA are strongly influenced by burrowing infauna and that direct excretion by osmoregulating animals may be an important source of TMA in the sediments. However, to understand the quantitative role of TMA in the mineralization processes of coastal sediments, the present characterization of TMA pools and their likely origin must be followed by direct measurements of TMA turnover.

Acknowledgements. This work was supported by the Commission of the European Communities (Contract No. ENV822-DK). We gratefully acknowledge Birte Eriksen and Else B. Frentz for their technical assistance and Anni Jensen and Marianne Szygenda for typing the manuscript.

\section{LITERATURE CITED}

Blunden, G., Gordon, S. M., McLean, W F. H., Guiry, M. D. (1982). The distribution and possible taxonomic significance of quaternary ammonium and other Dragendorffpositive compounds in some genera of marine algae. Botanica mar. 25: 563-567
Cavalieri, A. J., Huang, A. H. C. (1981). Accumulation of proline and glycine-betaine in Spartina alterniflora Loisel. in response to $\mathrm{NaCl}$ and nitrogen in the marsh. Oecologia (Berl.) 49: 224-228

Di Corcia, A., Samperi, R., Severini, C. (1979). Improvements in the gas chromatographic determination of trace amounts of aliphatic amines in aqueous solution. J. Chromatogr. $170: 325-329$

Fiebig, K., Gottschalk, G. (1983). Methanogenesis from choline by a coculture of Desulfovibrio sp. and Methanosarcina barkeri. Appl. environ. Microbiol. 45: $161-168$

Glob, E., Sørensen, J. (in press). Determination of dissolved and exchangeable trimethylamine pools in sediments. J. microbiol. Methods

Hebard, C. E., Flick, G. J., Martin, R. E. (1982). Occurrence and significance of trimethylamine oxide and its derivatives in fish and shellfish. In: Martin, R. E., Flick, G. J., Hebard, C. E., Ward, D. R. (ed.) Chemistry and biochemistry of marine food products. AVI Publ., Westport, Connecticut, p. 149-304

Henriksen, K., Jensen, A., Rasmussen, M. B. (1984). Aspects of nitrogen and phosphorus mineralization and recycling in the northern part of the Danish Wadden Sea. Neth. Inst. Sea Res. Publ. Ser. 10: 51-69

Jensen, H. B., Jørgensen, K. S., Sørensen, J. (1984). Diurnal variation of nitrogen cycling in coastal, marine sediment. II. Nitrous oxide emission. Mar. Biol. 83: 177-183

Jørgensen, B. B., Okholm-Hansen, B. (1985). Emission of biogenic sulfur gases from a Danish estuary. Atm. Environ. 11: $1737-1749$

Jørgensen, B. B., Sørensen, J. (1985). Seasonal cycles of $\mathrm{O}_{2}$, $\mathrm{NO}_{3}^{-}$and $\mathrm{SO}_{4}^{2-}$ reduction in estuarine sediments: the significance of an $\mathrm{NO}_{3}^{-}$reduction maximum in spring. Mar. Ecol. Prog. Ser. 24: 65-74

King, G. M. (1984a). Utilization of hydrogen, acetate, and 'noncompetitive' substrates by methanogenic bacteria in marine sediments. Geomicrobiol. 3: 275-306

King, G. M. (1984b). Metabolism of trimethylamine, choline, and glycine betaine by sulfate-reducing and methanogenic bacteria in marine sediments. Appl. environ. Microbiol. 48: 719-725

King, G. M., Klug, M. J., Lovley, D. R. (1983). Metabolism of acetate, methanol and methylated amines in intertidal sediments of Lowes Cove, Maine. Appl environ. Microbiol. 45: 1848-1853

Lee, C., Olson, B. L. (1984). Dissolved, exchangeable and bound aliphatic amines in marine sediments: initial results. Org. Geochem. 6: 259-263

Naumann, E., Hippe, H., Gottschalk, G. (1983). Betaine: new oxidant in the Stickland reaction and methanogenesis from betaine and L-alanine by a Clostridium sporogenesMethanosarcina barkeri coculture. Appl. environ. Microbiol. 45: 474-483

Oremland, R. S., Polcin, S. (1982). Methanogenesis and sulfate reduction: competitive and noncompetitive substrates in estuarine sediments. Appl. environ. Microbiol. 44: 1270-1276

Revsbech, N. P., Jørgensen, B. B., Blackburn, T. H., Cohen, Y. (1983). Microelectrode studies of the photosynthesis and $\mathrm{O}_{2}, \mathrm{H}_{2} \mathrm{~S}$ and $\mathrm{pH}$ profiles of a microbial mat. Limnol. Oceanogr. 28: 1062-1074

Sorensen, $J$. (1978). Capacity for denitrification and reduction of nitrate to ammonium in coastal marine sediment. Appl. environ. Microbiol. 35: 301-305

Sørensen, J., Jorgensen, B. B., Revsbech, N. P. (1979). A. 
comparison of oxygen, nitrate and sulfate respiration in coastal marine sediments. Microb. Ecol. 5: 105-115

Strom, A. R. (1979). Biosynthesis of trimethylamine oxide in calanoid copepods. Seasonal changes in trimethylamine monooxygenase activity. Mar Biol. 51: 33-40

Strøm, A. R., Larsen, H. (1979). Anaerobic tish spoilage by bacteria. 1. Biochemical changes in herring extracts. J. appl. Bacteriol. 46: 531-543

Yancey, P. H., Clark, M. E., Hand, S. C., Bowlus, R. D., Somero, G. N. (1982). Living with water stress: evolution of osmolyte systems. Science 217: 1214-1222

This article was presented by Professor T Fenchel; it was accepted for printing on April 28, 1987 